\title{
Publisher Correction: Ex vivo real-time monitoring of volatile metabolites resulting from nasal odorant metabolism
}

\author{
Aline Robert-Hazotte, Rachel Schoumacker, Etienne Semon, Loïc Briand, Elisabeth Guichard, \\ Jean-Luc Le Quéré, Philippe Faure \& Jean-Marie Heydel
}

Correction to: Scientific Reports https://doi.org/10.1038/s41598-019-39404-x, published online 21 February 2019

The original version of this Article was published with an incorrect version of the Supplementary Information file due to a technical error. This has now been corrected in the HTML; the PDF version of the paper was correct from the time of publication.

(c) (i) Open Access This article is licensed under a Creative Commons Attribution 4.0 International cc) License, which permits use, sharing, adaptation, distribution and reproduction in any medium or format, as long as you give appropriate credit to the original author(s) and the source, provide a link to the Creative Commons license, and indicate if changes were made. The images or other third party material in this article are included in the article's Creative Commons license, unless indicated otherwise in a credit line to the material. If material is not included in the article's Creative Commons license and your intended use is not permitted by statutory regulation or exceeds the permitted use, you will need to obtain permission directly from the copyright holder. To view a copy of this license, visit http://creativecommons.org/licenses/by/4.0/.

(C) The Author(s) 2019

Centre des Sciences du Goût et de l'Alimentation, UMR 6265 CNRS/1324 INRA/Université de Bourgogne FrancheComté, 9 boulevard Jeanne d'Arc, F-21000, Dijon, France. Correspondence and requests for materials should be addressed to J.-M.H. (email: jean-marie.heydel@u-bourgogne.fr) 